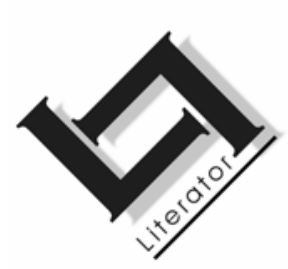

\title{
The technique of flashback in selected Northern Sotho literary texts
}

\author{
M.J. Mojalefa \& R.S. Phala \\ Department of African Languages \\ University of Pretoria \\ PRETORIA \\ E-mail: jerry.mojalefa@up.ac.za
}

\begin{abstract}
The technique of flashback in selected Northern Sotho literary texts

This article aims at investigating and explaining the application of the technique of flashback in selected Northern Sotho literary texts. Five kinds of flashback are distinguished, namely external retrospection, internal retrospection, mixed retrospection, flashback to complicate events and flashback of similar events. These kinds of flashback have certain and specific functions, such as reminding readers of past events, foregrounding themes of the text, and so on. This technique is evident in a text when ordinary, everyday events turn out to be the key to surprising secrets that are revealed later. Though flashback seems to be similar to foreshadowing (prolepsis) in that both techniques contain features of repetition and the narration of a specific experience, the techniques, however, differ in that flashback focuses on the elements of secrecy, suspense and surprise, and foreshadowing does not. This article also reveals that a relationship between flashback and the structure of detective stories can be indicated.
\end{abstract}

\section{Opsomming}

Terugflitse as tegniek in geselekteerde Noord-Sotho literêre tekste

Die doel van hierdie artikel is om die toepassing van terugflitse as tegniek in enkele literêre tekste in Noord-Sotho te verduidelik en toe te pas. Terugflitse as literêre tegniek kan onderverdeel word in vyf soorte, te wete eksterne, interne en gemengde 
retrospeksie, die terugflits om gebeure te kompliseer, en dié om gelyksoortige gebeurtenisse op te roep. Elkeen van hierdie vorms het ' $n$ besondere funksie, soos onder andere om die leser aan vorige gebeurtenisse te herinner of om bepaalde tematiese besonderhede na vore te bring. Die tegniek van terugflits is aantoonbaar wanneer gewone, alledaagse insidente later die sleutel word vir verrassende geheime wat onthul word. Ofskoon terugflits en vooruitskouing albei deur herhaling en die vertel van 'n besondere ervaring gekenmerk word, verskil hulle hierin dat terugflits op die elemente van geheimhouding, spanning en verrassing fokus en vooruitskouing nie. Die artikel wys ook op die verband tussen die tegniek van terugflits en die struktuur van speurverhale.

\section{Introduction}

Flashback is one of the techniques used in what narratologists call the second level of a text, that is the plot. Strachan (1990:101) and Genette (1980:49) list different kinds of these techniques that can be distinguished. Strachan (1990:101) for instance states:

... a distinction can be made between external retrospection (which lies outside the space of time of the primary story), internal retrospection (which lies inside the space of time of the primary story) and mixed retrospection (which begins outside the space of time of the primary story and ends within it).

In fact Strachan lists three kinds of flashback: (a) external retrospection, (b) internal retrospection and (c) mixed retrospection. Though this categorisation is widely accepted, it is problematic in that it does not include all kinds of flashback. Therefore, the aims of this article are firstly, to make necessary additions to Strachan's list of different kinds of flashback, secondly to investigate the application of flashback in selected Northern Sotho literary texts, and thirdly to establish the relationship between flashback and the structure of detective stories. This investigation of flashback will be conducted under the following headings: flashback as a narrative technique, kinds of flashback, flashback in selected Northern Sotho literary texts and the relationship between flashback and the structure of detective stories.

\section{Flashback as a narrative technique}

Before flashback can be defined it is important to explain the concept of narrative technique, since flashback itself is a narrative technique. Groenewald (1995:32) describes narrative technique as the arranging of events by confirming or disconfirming them, while 
Mojalefa (1995:24) contends that narrative techniques are different ways authors can choose to arrange the events in literary texts. As to the function of narrative techniques, the Russian Formalists hold that the major function is to change the usual usage of an object, event or word. Groenewald (1995:32) lists two additional functions, firstly to emphasise, develop and confirm a particular idea, and secondly to correlate that idea with the theme of the text. Though the functions of narrative technique as explained by these theorists are widely accepted, none of these explanations address an important contributing factor determining these functions, that is, the milieu in which a technique is used.

Mojalefa (1995:24) divides narrative techniques into two groups: techniques related to text types, such as poems, dramas, shortstories and so on, and techniques related to text structure, that is plot and style. Flashback belongs to this second group.

According to Mafela (1997:126) and Baldick (1990:9) flashback implies the narrator's interruption of the chronological sequence of events in a literary work. By inserting past events while facing new ones, the narrator relates both sets of events.

Cuddon (1979:27) summarises the functions of flashback. This technique reminds the reader of past events; reveals and develops themes of a text; and supplies background information of characters and events. Mafela (1997:129) confirms this by saying:

Flashback is the technique mostly used by authors to supply background information of characters and events. The author waits until things are moving and then goes back to fill in the necessary background information.

\section{Kinds of flashback}

There are five kinds of flashback identifiable in Northern Sotho literary texts - three listed by Strachan and two additional kinds identified in this article. Each of these will be explored, beginning with the categories of flashback identified by Strachan.

\subsection{Strachan's classification}

Strachan (1990:101) as well as Genette (1980:49) lists three kinds of flashback: external retrospection, internal retrospection and mixed retrospection. These three kinds of flashback will now be analysed. 


\subsubsection{External retrospection}

In external retrospection prior events recalled in the text lie outside the space of time covered by the primary story (Strachan, 1990:101; Genette, 1980:49). This kind of flashback thus provides the reader with information about what has happened before the story has started. For example, in Lenong la Gauta (Bopape, 1982:28-29) the death of Mmatšhego is first related and then, using external retrospection, more about her previous life in Gauteng is revealed in order to emphasise her viciousness.

\subsubsection{Internal retrospection}

Strachan (1990:101) and Genette (1980:49) indicate that when this kind of flashback is applied, the reader, while facing new events, recalls past events from within the space of time covered in the primary story. The importance of these past events is that at the point of their insertion they serve to supplement "incompleteness" in the text. Past events are thus presented so that the origins of the new events can be understood. For example, in "Ralato I" (Nka se lebale) the narrator uses internal retrospection by inserting the newspaper report to explain why Ralato does not make it to the church on the day of his marriage (see Motuku, 1972:71). In this case the technique functions to confuse readers, suddenly showing Ralato to be an evil man.

According to Swanepoel (1989:80) and Genette (1980:102), internal retrospection implies two aspects, namely completing and repeating.

Rimmon-Kenan (1983:47) states that both internal and external retrospection can be either heterodiegetic or homodiegetic in nature. Homodiegetic retrospection provides past information about the same character, event or story-line mentioned at that point; whereas heterodiegetic retrospection provides information about another character, event or story-line.

\subsubsection{Mixed retrospection}

This kind of flashback is a combination of both external and internal retrospection (Strachan, 1990:101; Genette, 1980:49). In mixed retrospection the contents of the flashback begin in the pre-story and stretch right into the primary story's space of time. In Letsogo la Molao (Mphahlele, 1984:33), for example, this kind of flashback is applied by inserting past events of Mathipa's life in order to reveal Reverend Makubu's character traits. 


\subsection{Additional kinds of flashback}

The theories of Strachan (1990) and Genette (1980) actually leave space for at least two other kinds of flashback, namely flashback to complicate events, and flashback of similar events.

\subsubsection{Flashback to complicate events}

This first additional kind of flashback includes two sub-groups: firstly, flashback that inserts events and secondly, those that change the chronological order of events. Flashback to insert events actually comprises Strachan's three kinds of flashback, that have already been discussed. Flashback to change the chronological order of events involves swapping events, for example an earlier event $A$ narrated after an explanation of a later event $B$. This means the chronological sequence A, B, C becomes for example C, B, A. Examples from Northern Sotho literarary texts include Megokgo ya Bjoko (Matsepe, 1968), in which the story starts with a court case, the cause of which is only told in the next chapter; and Ke dirišitšwe ke Wena (Phasha, 1994), in which the narration commences with the baby being thrown into the pit latrine - an event that is actually the concluding event in the story-line. This way of narrating events, of course, can have very particular and varied narrative functions.

A comparison of these two kinds of flashback, namely flashback to insert events and flashback to change the chronological order of events, reveals that though they both function to complicate events, they are in fact very different in nature. This difference lies in the fact that flashback to change the order of events involves in content only one event, whereas flashback to insert events involves at least two events. These two kinds of flashback also often perform different functions.

\subsubsection{Flashback of similar events}

When this kind of flashback is applied, a particular event is presented at the beginning of a text, and ignored at this point, but later towards the end of the story recalled by the narration of an event similar to the first event. A good example in this regard is Letsogo la Molao (Mphahlele, 1984), in which an incident, the hanging of convicts, occurs at the beginning of the story when the hanging of the outsiders are reported, and is then repeated again at the end, with the hanging of the Faros. The two events are intertwined and perform their function together. 
These five kinds of flashback all share the following features: the events they use are always common, unsurprising and everyday in nature, and the implied importance of these events are hidden from the reader.

\section{Flashback in selected Northern Sotho literary texts}

The application of the technique of flashback will be investigated according to the different kinds of flashback: flashback to complicate events, flashback to change the chronological order of events, and flashback to insert events (with its three subtypes external retrospection, internal retrospection and mixed retrospection), and flashback of similar events.

\subsection{Flashback to change the chronological order of events}

Changing the chronological sequence of events involves the author swapping events that should follow one another in sequence, or starting the narrative with an event that should only come later. To investigate this kind of flashback, two novels will be examined, namely Matsepe's Megokgo ya Bjoko (1968) and Phasha's Ke dirišitšwe ke Wena (1994).

In the novel Megokgo ya Bjoko events start with a court case in the first chapter (Matsepe, 1968:1):

Banna ba ohlile maledu kua kgorong, moo megopolo ya bona e šetšego e babaela. Ga se ka phošo ka gore ke matšatši e le leetong le molato woo, le ge la mathomo o be o sa abula, lehono o šetšego o ithuta mmemi le go katiša.

[Men braid beards at the kraal, where their minds are already in a condition of being mentally very tired. This is not by mistake, because the trip to the case will take many days; though it began by crawling, today it is already starting to stand, and learning to walk.]

When events are told in this fashion, readers soon realise that something has happened which is not revealed at this stage. The chapter thus concludes by stating:

Ke nnete gore Leilane o iteile mogogadi, ke nnete gape gore $o$ iteile mosadi wa gagwe, gomme hle bana bešo, le tla ntshwarela ge ke re le nna nka be ke dirile ka moo Leilane a dirilego ka gona, ka gore le ge go lefa nka lefa - le bona ba tla šala le mabadi, le gona ba tla tlwaologa go hlatšišwa ke tše ke di jago. Dihlaa ke tša ka, mpa ke ya ka, bjale o tshwenywa ke 
eng? Ke nnete gore o ba iteile, gomme ditaba tša ntshe di tlile ka tsela ye: (Matsepe, 1968:2-3.)

[It is true that Leilane has beaten his father-in-law. It is also true that he has beaten his wife. Now, my dear brother - you will forgive me when I say I would have done the same as Leilane has done, even if I had to pay the fine and they remain with scars, if only to stop them vomiting next to me when I eat! The taste buds are mine, the stomach is mine, and now what worries you? It is true that he has beaten them, and the events have developed in this way:]

This piece of comment indicates that the events are not in the correct order and with this kind of flashback the sequence is corrected. Therefore, in the second chapter the events are narrated that explain why Leilane had to come to court. These events can be summarised in this way:

There is drought throughout the whole country; drought that results that many cattle die of hunger. Leilane's cow in calf has to be put down, and Leilane cooks and eats the embryo. When his wife, Mohlatša, sees him eating the embryo, she starts to vomit - an act that triggers Leilane's anger and he beats her with his kierie. In pain, Mohlatša rushes back to her parents' home. When her father tries to ask Leilane why he has beaten Mohlatša, Leilane beats the old man too. When they try to negotiate to solve the problem as a family, Leilane prefers to take the matter to the chief's kraal.

As the story unfolds the reader realises that, if a strict chronological order were followed, these events would have been narrated at the beginning of the story line and the court case later on (in the second chapter).

Again, at the end of the second chapter, events are related that will be explained in chapter three:

A ba nyaretše ka pela ka ge nnete gona le dikela, gobane ba gana a re a e be sekomanyanakomana etšwa ba tseba gore kgomo ka mo gobe e wetšwa ke namane. Ge bjale ba gana ge yena a re a bolawe na ba gopotše gore lešaba le lekaaka la Nthumule le swanetše go tla go fela ka lebaka la Leilane? Aowaowaowaa! Go ile gwa tla gwa ba bjang? (Matsepe, 1968:30.)

[Let them decide quickly because the truth is that the sun is setting, and they refuse to kill him though they know that the cow is put in danger by its calf. When they now refuse to have him killed - do they think that the whole nation under Nthumule 
should perish because of Leilane? No ... no ... no! What will happen then?]

This extract suggests that when Chief Nthumule's subjects accept Leilane, this causes problems for them. What these problems are has not been told, and will only be explained in the next chapter. These problems are revealed to be the following:

After Maphuthe has not been allowed to keep Leilane, Maphuthe unties him at night. When he is found missing the next morning, the chief calls together all the witch-doctors. Their divining is, however, disturbed by a miraculous event: the knucklebones used by these witch-doctors are all picked up and swallowed by black hawks. After this incident, war follows, and most of Nthumule's warriors die. This technique thus changes the sequence of events in these two chapters by beginning with events that are supposed to come later. In this way, the readers of the text find themselves confused.

This use of flashback to change the chronological order of events can have two functions, namely firstly, to arouse interest and secondly, to reveal the character of the narrator. These functions in Matsepe's Megokgo ya Bjoko (1968) will be discussed in turn.

The reader's interest in this novel is first roused by the technique of beginning the story line with the court case. Arranging the events in this fashion creates interest because the complicated events of the trial, that are initially confusing, seem to be explained towards the end of the chapter, as indicated by the paragraph quoted previously. By means of this paragraph then, the reader is motivated to continue reading in order to understand the state of affairs. Thus the reader's interest grows.

According to Groenewald (1993:52) the second function of flashback in Matsepe's novel, that is to change the chronological order of events, is applied also to reveal more about the character of the narrator. This statement can be illustrated from the novel:

- The narrator is a person who does not mind lying e.g.

Se tshwenyege ge ba re o huane, ka gore, ka gona go bolela maaka - o re tloša bodutu (Matsepe, 1968:9.)

[Do not worry when they say you are a liar, because through telling lies you entertain us.]

- The narrator has an idea or philosophy about African life, that is an explanation of something that happens in the life of any person, e.g. 
Re llela go phela, re llišwa ke go phela ...

(Matsepe, 1968:38, 48).

[We cry for life, life makes us cry ...]

- The narrator reveals details about events that he too does not know fully. Often he pleads on behalf of himself and the readers that they be told what they do not know e.g.

Aowa, re tleleng natšo hle (Matsepe, 1968:2).

[Narrate the story to us.]

- The narrator sometimes denies what he has said before - a strategy that can lead to readers mistrusting him e.g.

Ga ke gane bana bešo, nama ke a e hwela ka ge mogologolo a šetše a ile a re ga e bjalwe. Fela godimo ga go ja serapolotšwana gona aowaowaowaa (Matsepe, 1968:6).

[I don't deny, dear brothers, that I hunger for meat; as an oldtimer already has said, meat does not grow - but rather than eating an embryo, I say no, no, no!]

- The narrator inserts events not related to Leilane's story, like those that involve the Huane, TIhahlathi and Rathinyane families. These events have two functions. The first is to remind readers of the narrator's presence, and thus of his fallibility. The second is to emphasise an idea or a lesson related to social problems, for example aggressiveness, cheekiness or bullying.

- The narrator sometimes uses shifting points of view to arouse the reader's interest. Using this technique the narrator is able to contrast overall truth with individual subjective understanding. This shifting point of view in Matsepe's Megokgo ya Bjoko utilises three registers of the narrator's style:

- The narrator makes subjective statements e.g.

Re llela go phela, re llišwa ke go phela (Matsepe, 1968:1).

[We cry to live, and life makes us cry.]

- He simply narrates e.g.

Banna ba ohlile maledu kua kgorong ... (Matsepe, 1968:1).

[Men braided beards at the kraal.]

- The narrator teaches e.g.

Šedio lena badimo - jang bose ... (Matsepe, 1968:92).

[There, you are the gods/ancestors - enjoy yourselves ...] 
All these characteristics of the narrator in Matsepe's novel can be combined to form a profile of the narrator. The narrator is fallible, and what he says is untrustworthy. He likes to use irony and play the fool with the reader. In the end the manner in which the narrator relates the events of this novel makes it read like an ironic or comic novel, while in fact it is a tragedy. By doing this, the narrator increases the readers' interest because true events are mixed up with imaginary ones.

We now turn to the novel Ke dirišitšwe ke Wena by Phasha (1994). The use of flashback to change the chronological sequence of events is seen right at the beginning when it is narrated how Dipono sees Dintenne and nurse Baile throwing a baby into a pit latrine:

Dipono o reng a bona masetlapelo mola a be a sa bapadiša banana ka kgopolong ya gagwe? O reng a šulelwa ke leeto a be a mona menwana ka lebaka la mantlwantlwane ao a bego a bapalwa monaganong wa gagwe? Ngwana ..., lekgarebe ... mooki ... botshewelamare, aowa, naa ke reng? Afa ke tloga ke bona gabotse? (Phasha, 1994:2).

[Why does Dipono see tragedy when she is busy playing with toys in her mind? Why doesn't she enjoy playing them while she is sucking her thumb because of the children's games still running through her mind? Baby ... young lady ... nurse ... toilet ... No, what do I say? Do I really see clearly?]

This is clearly an event that requires an explanation, though this explanation only comes much later at the end of the novel. Therefore, it is clear that the narrative begins with an event that is actually not the beginning of the story. The narrator points out the rearranging of events, saying,

Ke le boditše gore nna ke tloga ke di kwele pele ga ge Dipono a di bona. Tša gagwe di rotogile ka tsela ye

(Phasha, 1994:3).

[I told you that I had heard this long before Dipono could see these events. Her version of the events emerged in this way.]

The narrator then informs the reader what kind of person Nurse Baile is. This information can be summarised briefly:

Nurse Baile is apparently an ordinary person, quiet and respected. She seems to live happily with her husband. However, though she works at the hospital, she earns additional income by conducting illegal abortions. 
When all this information about Baile is known to the reader, the narrator can continue, saying,

Bjale ge bana bešo, naa Dintenne ke mang? O reng a lla a etšwa ka botshwelamare? Afa le tloga le ekwa tšeo di kwewago ke nna? Dintenne o reng a etla ga Mooki Baile ge e le gore o a babja? Beng ba tšona bao ba go kwa gore di hlolegile bjang ba re di hlolegile ka tsela ye: (Phasha, 1994:6).

[Now, my dear brothers, who is Dintenne? Why is she crying coming from the toilet? Do you really hear what I hear? Why is Dintenne going to Nurse Baile if she is ill? Those who are concerned and who were involved explain what happened in this way:]

From this point onwards the narrator starts giving information about Dintenne's family, her love-affair with Mothubi, her pregnancy, her kidnapping by Dintlabile and her attempt to murder her baby. Thus readers finally realise that these two events, the one concerning Baile, and the one concerning Dintenne, actually occurred at an early stage in the chronological order, while throwing the baby into the toilet is the final event in the sequence. In chronological sequence the events follow the order $\mathrm{A}, \mathrm{B}$ and $\mathrm{C}$, while the order of the plot of the novel is changed to $C, B, A$.

As in Matsepe novel, the technique of flashback is used in Phasha's novel by changing the usual chronological order of events to arouse reader interest, making the text more exciting and appealing. The author accomplishes this aim firstly by means of the diction he uses, for example the list of words quoted above that explains what Dipono sees:

Ngwana ... lekgarebe ... mooki ... botshwelamare

(Phasha, 1994:1).

[Baby ... young lady ... nurse ... toilet]

Though the reader eventually, at the end of the book, realises how these words fit the event, these words at first sight are very confusing, thus causing the reader to become interested and read further in the hope of solving the mystery of these words' meaning. Thus the narrator chooses to start the narrative with this event, which is supposed to be last in the sequence of the plot, with the aim of attracting the reader's attention. Readers thus realise that this event carries more weight than does the event that, in strict chronological sequence, should have come first. 
Also, beginning the plot with the event of throwing the baby into the toilet causes the reader to read the text with this tragedy in mind. This event creates a feeling of sadness and sympathy with the baby's mother in the reader's mind, since the reader realises that even though Dintenne has committed a crime she has suffered terrible misfortunes.

\subsection{Flashback to insert events}

In this case, the author inserts previous events during the course of the narration. As has been discussed, this kind of flashback can be distinguished by three different subtypes, namely external retrospection, internal retrospection and mixed retrospection.

\subsubsection{External retrospection}

By applying this kind of flashback the author reverts to events which happened at the beginning of the text, while the story is heading towards its conclusion. To illustrate this subtype an example from the novel Lenong la Gauta (1982) by Bopape will be examined.

In this novel external retrospection is used by inserting the story of Mmatšhego at the stage when she still stayed in Johannesburg:

O a bona Nnono, mengwaga ye mene ya go feta ge ke nyalane le Mmatšhego, ke be ke sa tsebe selo ka yena gomme le ge a sa ke a bolela kudu, gagolo bophelo bja gagwe bjo bo fetilego, ke ithutile sengwenyana ka bjona ... Mmatšhego o bile le bophelo bja manyami a magolo ka gore o nyetšwe la mathomo ge a sa na le mengwaga e masomepedi-hlano eupša monna wa gagwe ga se a ke a gola go ipshina naye ka ge a ile a rathwa ke legadima morago ga mengwaga ye mene. Morago ga mengwaga ye mebedi, o ile a nyalwa ke monna wa mohlolo yo a bego a na le sa gagwe ka gore mengwaga ye seswai ya go feta ge a hlokofala, o ile a tlogelela Mmatšhego lefa la go tsebalega ...Taba ye nngwe ke gore Mmatšhego o be a na le dilwana tše mmalwa tša go dirwa ka taamane. Dilo tše ka moka go itaetša a di humane go monna yoo wa mohlolo.

(Bopape, 1982:28-29).

[You see, Nnono, during the past four years of my marriage with Mmatšhego, I knew nothing about her. She does not talk much, especially about her previous life. I have now learnt about her previous life. Mmatšhego was unhappy in her youth, because of her first marriage at the age of fifteen. She was never happy with her first husband. He was struck by lightning after they had been together for four years. Two years later she married a rich widower and eight years ago when he died he 
left Mmatšnego a lot of riches. The other thing is that Mmatšhego has a lot of jewellery. She has two or three diamond rings. Apparently she got all these from the widower.]

This information about the earlier stages of Mmatšhego's life is very important, since it gives the reader a first impression of the character of Mmatšhego; she seems to be a good woman, with much perseverance, but an introvert. This information also explains why someone could consider murdering her for her wealth. At a later stage in the narration a golden necklace shaped like an eagle is given particular prominence.

This use of external retrospection in the novel thus functions to explain the character of Mmatšhego, so that when the event when she is murdered (towards the beginning of the plot), the reader feels pity for her, since she seems to be a good and innocent person. This information also causes the turn of the plot to be much more effective - at this stage and by means of Mr. Maleka's story about Mmatšhego's early life in Gauteng the reader begins to realise that she is actually a criminal. Then she is suddenly no longer the Mmatšhego the reader knew, but has become a bad person. The explanation reveals her true character. At the beginning of the plot, therefore, her true character and history are kept secret, and the author complicates the events of the plot to keep the secret hidden right up to the end. This means that the reader's interest is maintained and increased throughout the plot, as people start to be inquisitive as to the real character of the deceased.

\subsubsection{Internal retrospection}

Internal retrospection is the second subtype of flashback and implies inserting events. Characteristic of this kind of flashback is that during the course of events the focus will shift and go back to events that happened within the plot itself. To investigate this kind of flashback, Motuku's short story "Ralato I" (Motuku, 1972) will be examined.

At the outset of the short story the following characters are present: Rev. Malebo and a bride, Rebotile, together with witnesses, gathered in a church for a wedding. All of them are, however, surprised by the absence of the groom, Ralato. To present this surprise, the narrator uses the priest's words:

Ngwanaka, nako ya ka ya go le tšeiša e putlagane. Hleng lesogana la gago ga le bonale? (Motuku, 1972:1).

[My child, my time to join you in wedlock has expired. Why has your boyfriend not shown up?] 
In her moment of surprise Rebotile replies the priest as follows:

Moruti, le nna ke a makala gore naa moratiwa wa ka Ralato a ka be a swerwe ke eng. Ga ke kgone go gopola gore molato e ka ba e le eng gobane maabane thapameng re be re le mmogo, gomme a tlišetša kopano ye ya rena mo (Motuku, 1972:1).

[Pastor, I am also surprised; what could be holding up my lover, Ralato? I cannot imagine what the cause could be, because yesterday evening we were together and he confirmed his coming here.]

This piece of dialogue between Rev. Malebo and Rebotile reveals the predicament the characters are in and that neither of them has any vestige of an idea of where Ralato might be. But as the short story progresses, this uncertainty is removed by using the information in a newspaper report:

Mna Ralato Thipe, yo atrese ya gagwe e sa tsebjego gabotse fela go kwalago gore o tšwa go la Tshwane, Bokwena bja Mogopa, moo ba rego ke Hebron, o swerwe maabane mesong motseng wa Kgalauwane, gomme o hlahletšwe kgolegong ya Nebo. Monna yo ke yo mongwe wa mafadi ao e lego manaba a lefase la gaborena la Repapoliki ya Afrika-Borwa. Ke yo mongwe wa bao ba thušago manaba a lefase la gaborena. Manaba ao boikemišetšo bja bona e lego go senya tše botse ka moka tšeo mmušo wa rena o re direlago. Molato wa gagwe o befile kudu ka maatla, moo e lego gore go ahlolelwa mengwaga ye mentši kgolegong go ka se makatše. Ba mohuta wa Ralato ga ba tsomege lefaseng la gaborena ka ge ba ferehla batho ba lefase ka go khupetša botse ka bobe mahlong a batho. Le ba hlokomeleng ke diphiri tše di gagolago matlalong a dinku

(Motuku, 1972:71).

[Mr Ralato Thipe, whose address, though not well known, is said to be somewhere at Tshwane, Bokwena or Mogopa, or alternatively said to be in Hebron, was arrested yesterday morning at the village of Kgalauwane and is being kept in Nebo prison. This man is a notorious enemy of the Republic of South Africa, who helps the enemies of our country whose aims are to sabotage all good things done for us by the government. The case against him is so serious that a sentence of many years will not be surprising. People of the calibre of Ralato are not wanted, since they deceive other people. Look out for them, for they are wolves in sheep's clothing.]

The newspaper report functions as an illustration of internal retrospection, because previous events are inserted as the story line proceeds. 
The use of internal retrospection in this short story by Motuku functions to confuse readers. As the story begins Ralato is presented as a decent person about to be married. His absence from the church, though the priest, the bride and the witnesses are all waiting, however, raises suspicion; and then the newspaper report confirms this suspicion, by showing Ralato in a changed light, and revealing him as a bad person. Thus the narrator uses the technique of not directly revealing Ralato's character and keeping some details a secret. These details are only revealed at the climax of the story when Major Schoeman says that Ralato has been working as a secret detective.

\subsubsection{Mixed retrospection}

This kind of flashback to insert events is utilised when information about previous incidents are inserted when events are heading towards a climax. In order to investigate this kind of retrospection the novel Letsogo la Molao (1984) by Mphahlele serves as an example.

The use of mixed retrospection in this book is presented by means of inserting previous events involving Mathipa. The presentation of these events begins as follows:

Morena Mathipa o be a dula kgojana, ka kua Meadowlands. Yena mong 0 be a re o dula Number 4765 Zone two, Meadowlands. Ke mokgalabje wa mengwaga ya go obamela masomešupa, wa lerapo le lethata, o be a sa kgona go fihla Phomolong ka maoto. Makgowa a gagwe a ile a mo laya tsebe go kwa ge a rola modiro gore a no fela a sepelasepela ka maoto go ikotlolla; go sego bjalo, a ka tla a ipiletsa bokgalabje le bolwetši a hwa. Bjale ga a lebale mantšu ao (Mphahlele, 1984:33).

[Mr Mathipa lives quite far away, in Meadowlands. He himself alleges that he lives at number 4765, Zone two, Meadowlands. $\mathrm{He}$ is an old timer of over seventy years of age, well-built, tall, and can still walk on foot to and from Phomolong station. His white employers have advised him to keep on walking after retirement, otherwise he will invite aging, disease and ultimately early death, and he has not forgotten these words.]

This information explains the state of affairs. Readers start to understand Mathipa's reason for occasionally paying Pastor Makubu a visit on foot, namely the advice he has been given about taking regular exercise. 
Mphahlele uses mixed retrospection in structuring the events of this novel with the aim of revealing the importance of the old timer, Mathipa. This is necessary since Mathipa is in fact not the protagonist of the novel; Faro, however, is. Faro's story follows the structure of a classical tragedy. He is a person of high social standing (the son of a priest), who through his shortcoming becomes a criminal, loses his position in society and is hanged at the end. According to Groenewald (2000:69), although Faro is a criminal his childhood history is such that readers sympathise with him as he is about to be hanged. The readers' empathy with Faro and their sympathy with him are achieved through two other characters, his girlfriend Sarona and his father Makubu. Because of information disclosed by these characters readers are able to identify with Faro even though he is a criminal - a clever way of using mixed retrospection in the novel.

Groenewald (2000:63) explains that Sarona is a unique figure worthy of respect. To fill in details about the character of Rev. Makubu, the interaction between Rev. Makubu and his friend Matipa is utilised. Makubu, for instance, tells Mathipa about the events in prison, and does so with great remorse. This detail helps to reveal Makubu's character to the readers. Again, when Mathipa becomes aware of the trouble Faro is facing, the old man notifies Makubu, who ignores the news. This information clearly points to Makubu's shortcomings. Secondly, the narrator uses Mathipa to describe Makubu's character by building up a contrast between the two of them. Mathipa is portrayed as an alcoholic, a womaniser and a traditionalist - qualities that are contrary to everything Rev. Makubu stands for. However, Makubu is shown to like smoking above all things - something Mathipa cannot stand. The importance of Mathipa in this novel lies partly in the fact that through contrast he helps to give the character of Makubu stronger relief, by emphasising who Makubu actually is.

\subsection{Flashback of similar events}

If events are arranged in this way the narrator may present a particular event at the beginning of the text and then towards the end of the plot present an event similar to the one presented at the beginning. To analyse the use of this kind of flashback in Sepedi literature, the short story "Roko ye ntsho" by Puleng (1994) and the novel Letsogo la Molao by Mphahlele (1984) will be examined.

In the story "Roko ye ntsho" by Puleng (1994) events begin as the narrator presents Kobi and his wife, Mmalehu, in dialogue: 
Kobi: Mmalehu moratiwa, ke feditše le mogopolo wa ka gomme ke tšere sephetho.

Mmalehu (ka tlabego): Ke sephetho sa eng?

Kobi: Ngwaga wo o šupologago ke nyaka go ikhwetša ke le University of Alacrity (ka boikgantšho) kua lebopong la lewatle.

Mmalehu (ka pefelo): O thomile! O thomile Kobi!

Kobi (ka tlabego): Ke thomile eng?

Mmalehu (a hema ka bothata): Kobi! Ke neng o nkopelela koša ya yunibesithi, yunibesithi! ( $O$ a galefa). O mpotša matlakala. ( $O$ kgatla motswiri). Mpss! Sis!

Kobi (ka boleta): Aowa hle Mmalehu, mogatšaka. Na o reng o hlapaola dinepo le maikemišetšo a bokamoso bja ka le lapa le?

Mmalehu (ka go tlala pelo): Ga se selo tšeo. Bona! Gonabjale ke mmeleng. Ka mo re na le bana ba babedi. Gape, ga se wa fetša go aga mo gae. Batho ba tla re tšea bjang?

Kobi: Bona batho bao o ba šeditšego kudu, ba tla be ba fetogile dimumu mohla ke alogago, ke boa ke apere roko ye ntsho ya thuto (Puleng, 1994:23).

[Kobi: Mmalehu my wife, I have concluded my thinking, and I have taken a decision.

Mmalehu (surprised): What decision?

Kobi: This coming year I would like to see myself at the University of Alacrity (proudly) there at the sea coast.

Mmalehu (angrily): Now you've started, now you've started, Kobi!

Kobi (surprised): Started what?

Mmalehu (breathing heavily): Kobi, since when have you been singing the song of the university? University! (getting fed up) You are talking rubbish! Mpss! Sis!

Kobi (humbly): No, please, Mmalehu my wife. Why do you belittle my aims and intentions for my future and this family?

Mmalehu (still fed up): That's nothing. Look, l'm pregnant now, we have two kids, and you have not yet completed our house. What will people say of us?

Kobi: Those people you are paying great attention to will be dumb the day I graduate, wearing the black gown of academic achievement.]

This dialogue between Mmalehu and Kobi seems to be very ordinary, and the mentioning of the black gown merely part of a 
discussion of university education. But at the end of the story this particular is mentioned again:

Magagešo, bonang taba ye bohloko; Roko ye ntsho yeo mohu a bego a e llela, lehono še, e aperwe ke Mmalehu, mosadi wa gagwe (Puleng, 1994:42).

[My countrymen, look at the sad story; the black gown which the deceased cried out for, now worn by Mmalehu, his wife.]

At this point in the plot, the fact that the black gown is mentioned causes the reader to realise that the black gown of the title is not the academic gown Kobi hoped to wear after completing his degree, but actually represents mourning dress. The colour of the two gowns is alike, but their different purposes are used to surprise the reader.

We now move to Mphahlele's novel Letsogo la Molao (1984) in which the flashback of similar events involves two events. The first is the hanging of the prisoners in Tshwane, and the second the hanging of the Faros.

When Mathipa visits Rev. Makubu, the priest tells his friend of the events in the prison:

Ka kua dithapong ke mahlomoleng, Kolobe. Nna le ge ba ka ntefa sekete sa diranta ka kgwedi, nka se boelele go rapelela dibofša tšeo di ahloletšwego thapo. Ka nako ya 6.00 mesong bafegiwa ba fiwa difihlilo, dijo tša matsaka, tše bose go feta tša mehleng. Ba bangwe ba no itšhela mola ba bangwe ba gana go ja. Ka morago ga moo ba a gapša, ba bofilwe matsogo ka morago, mahlong ba pipilwe ka lešela le leso, ba išwa ntlwaneng yeo e nago le dithapo ka fase. Ge ba tsene ka moo, ga go sa dumelelwa motho, le moruti yoo a bego a ba rapelela, a ba kgothatša, o šala ka ntle. A ka no ba gona ge e šetše ba hwile, e le ditopo, goba a boa thapama go tla go ba boloka (letl.88) (Mphahlele, 1994:88).

[In the gallows room, it is frightening, Kolobe. Even if I were paid thousands of rands a month, I couldn't go and pray for the prisoners condemned to death. At six o'clock in the morning, the prisoners are given breakfast, food of a better quality than usual. Some eat, others refuse. Then they are taken, handcuffed hands at their back, with their faces covered with black cloth, to the small room with the rope. Once they enter that room, no one may accompany them, not even the priest who has been comforting them. He remains outside. He may only enter once they are dead, to come in the evening to bury the corpses.] 
This narrative reveals the shocking events witnessed by Rev. Makubu when prisoners are hanged. It seems as if the events he relates to Mathipa shocked the priest. Makubu is seen as sympathising with the prisoners even though he does not know them.

The second instance of a hanging in the novel comes towards the end of the story, when the narrator presents the hanging of the Faros. This event does not only shock Rev. Makubu, but also Themba's parents and Mathipa himself.

Go bolela e be e no ba sehebehebe. Mathipa o be a tšhogile la masetlapelo o ka re go ya yena thapong. Pelo ya gagwe e betha ka maatla kudu mola mala ona a tšhabile, o ka re ga go selo ka mo gare. O ile ge a botšiša gore moruti o ikwa bjang, moruti a re: "Ke kgotleletše dilo tše ntši kudu bophelong bja ka Kolobe. Ke fetile gare ga dikgabo tša mello; gare ga mešwana, megaletwa le mekgwaripa. Ke hwetšwe ke tate ke sa bala mphato wa bohlano, ka loga maano, ka šoma ka maikhutšo a dikolo, ka itapiša go fihlela ke fetša dithuto tša ka, le tša boruti. Le ge lehu la go fegwa e le sepoulo, lehu la Faro le ka se nthobe go swana le la mmagwe (Mphahlele, 1994:110).

[To talk was merely to whisper. Mathipa was as frightened as if he were the one to be hanged. His heart beat hard, while his intestines felt empty, as if there was nothing inside him. He asked the priest how he felt, and the priest replied, 'I have tolerated many things in my life, Kolobe. I have passed through great fires, through the thorn tree and many other types of bush. I lost my father when I was in grade seven, I had to make plans to work in the holidays to pay for my schooling, I persevered until I completed my education and my training for the priesthood. Though death by hanging is shameful, the death of Faro will not be as heavy to me as the death of his mother.']

Thus it can be seen that Mathipa experiences great shock when the Faros are hanged, and that even though in the dialogue with the priest it seems as if Makubu is not feeling the shock, Mathipa's shock suggests the priest's true feelings despite his numbed reaction. The shock experienced by Themba's parents is also described:

Ge ba boa go bašemane ke ge mmago Themba a farafarilwe ke mogatšagwe le moruti e le gore o nolegile moko, matolo a gana, mmele ka moka o thosogane. Bakgalabje bao ba babedi le bona ba be ba no šita kgang, ba re monna ke nku o llela teng. $\mathrm{Ba}$ be ba fetogile difahlegong, ba sehlefetše o ka re 
dipoko. Ba be ba tšhošitšwe ke bana ba bona (Mphahlele, 1994:110).

[When they returned after seeing the boys, Themba's mother accompanied by her husband and the priest, were all depressed, their knees shaking and their bodies numb. The two aged ones were just trying to hold themselves together, because man usually endures hardships in life. Their faces were changed; they were pale, as if they were ghosts. They were frightened by their children's fate.]

At this stage it becomes clear that Themba's parents are depressed by the hanging of their son. Their feelings of pain add even more to Makubu's suffering. The narrator also describes the state in which the Faros themselves are before their hanging:

Ba ba hweditše ba dubagane, ditho di rephile, ba palelwa le ke go no emelela le go bolela. Faro yena thapo e be e ile go no fofotša. Ka morago ga lebakanyana ditšhipi tša iri ya bošupa di ile tša lla. Go batswadi ba Faro le Themba ditšhipi tšeo di be di lla ka gare ga dipelo tša bona, di ba begela gore bjale molao o dira boithatelo ka bana ba bona. Gatee fela muši wo moteletšana o ile wa bonwa o re tsokee, o eya godimo marung, e le sešupo sa gore mphiri o kgatlile (Mphahlele, 1984:110).

[They themselves are highly depressed, limbs numbed, not even able to stand or to speak. For Faro, the hanging was just the end of something already finished. After some time the seven o'clock bell rang. To the parents of Faro and Themba, the ringing of the bell sounded in their hearts the knowledge that the law had taken its full course with their children. At that moment green smoke was seen, growing thinner towards the clouds, signalling that all was over.]

Before this passage, the impression is created that the boys' resistance is gaining momentum, but this description of their fright reveals the opposite, and the reader knows that the pain in Makubu's heart will only increase. Makubu's pain only seems less when compared to the description of Themba's parents' pain.

\section{The relationship between the technique of flashback and the structure of a detective narrative}

If this relationship is to be understood, the arrangement of events used by authors in detective narratives should be examined. Dresden and Vestdijk (1957:64) describes the arrangement of events in a detective narrative as follows: 
De Schrijver van detectiveverhalen moet van te voren de oplossing kennen en is verplicht de lezer langs hoeveel dwaalwegen dan ook naar deze oplossing te voeren om tevens te doen alsof hij zelf (en zijn detective) deze ontraadseling ook niet kende. Psychologisch besien, worden detectiveromans van achteren naar voren geschreven! De oplossing is de Schrijver van begin af bekend.

[The author of detective narratives has to know the end before beginning to write, and has the obligation to lead the reader down many winding paths before eventually supplying the solution, and to do this as if he (and his detective) are also still ignorant of the solution. Seen psychologically, detective narratives are written from the back to the front! The solution is known to the author from the beginning.]

According to the above description the author of a detective narrative begins the story line with events at the end of the story, and then later reverts to those at the beginning. For example, when the events of the plot of the short story "Ralato I'" (Motuku, 1972) are arranged, the narrator initially presents Ralato as a decent young man, but later in the plot the narrator inserts the newspaper report quoted previously in this article, thus confusing the reader by presenting Ralato as a bad person. At the end of the story, however, the solution to this mystery is provided by Major Schoeman, who indicates that Ralato is a private detective. The story ends with the arrest of the real criminals. The suspense prompts the reader to continue reading so as to discover the end and solution of the story.

Detective stories can actually be said to contain two narratives explaining one thing. One narrative is that of the lie, and the other the narrative of the truth. In "Ralato I" the narrative of the lie is evident when the narrator uses the newspaper article to present Ralato as a bad person, and the narrative of the truth is evident when the narrator uses Major Schoeman's revelation of Ralato's true character. A comparison of the narratives of lie and truth reveals that they are always linked. Another example from "Roko ye ntsho" (Puleng, 1994) is the black graduation gown, that is the lie, linked to the black mourning gown, that presents the truth.

In conclusion it can be stated that a distinct relationship between the technique of flashback and the structure of detective narratives exists. This relationship is particularly clear because both are concerned with a secret and the revelation of the secret. 


\section{Conclusion}

Flashback as technique used in plot construction has features by which it can be identified in a text, namely it has to do with ordinary events, these events end with a surprise and this surprise reveals the origin of the problem.

Within this technique five different kinds can be distinguished: flashback to complicate events, flashback to change the chronological order of events and flashback to insert events (with its three subtypes, that is, external retrospection, internal retrospection and mixed retrospection), and flashback of similar events. Flashback to change the chronological order of events and flashback to insert events differs in content in that flashback to change the chronological order of events concerns only one event, whereas flashback to insert events has to do with two events. The five kinds of flashback have certain functions to perform, the most important being to supply readers with background information concerning characters and events, to increase surprise and to confuse readers.

Even though the techniques of flashback and foreshadowing are very similar in appearance, as both have to do with repetition and the narration of a specific experience, they do differ. When the technique of flashback is applied the narrator seems to hide events from the reader only to reveal them later - thus causing surprise and amazement. Flashback is related to detective narratives, as they both involve a secret and its revelation.

\section{List of references}

BALDICK, C. 1990. The concise Oxford dictionary of literary terms. Oxford: Oxford University Press.

BOPAPE, H.D.N. 1982. Lenong la Gauta. Pretoria: Van Schaik.

CUDDON, J.A. 1979. A dictionary of literary terms and literary theory. New York: Penguin.

DRESDEN, S. \& VESTDIJK, S. 1957. Marionettespel met de dood. The Hague: Bakker.

GENETTE, G. 1980. Narrative discourse. Oxford: Blackwell.

GROENEWALD, P.S. 1993. Thutadingwalo ya Sesotho sa Leboa 1. Pretoria: Via Afrika.

GROENEWALD, P.S. 1995. Thutadingwalo ya Sesotho sa Leboa 4. Pretoria: Via Afrika.

GROENEWALD, P.S. 2000. Letsogo la Molao: 'n stilistiese analise van 'n prosateks. South African Journal of African Languages, 20(1):61-69.

MAFELA, M.J. 1997. Flashback and the development of action in T.H. Makuya's short story "Vho-Dambala". South African Journal of African Languages, 17(4):126-129. 
MATSEPE, O.K. 1968. Megokgo ya Bjoko. Johannesburg: Educum.

MOJALEFA, M.J. 1995. Ntlhahle ya Bobedi (BA) Sepedi 202. Pretoria: University of Pretoria.

MOTUKU, H.Z. 1972. Ralato I. (In Motuku, H.Z. \& Ramokgopa, H.H. Nka se lebale. Bloemfontein: Via Afrika. p. 65-86.)

MPHAHLELE, M.C. 1984. Letsogo la Molao. Pretoria: De Jager-Haum.

PHASHA, R.R. 1994. Ke dirišitšwe ke Wena. Pretoria: Van Schaik.

PULENG, N.S. 1994. „Roko ye ntsho. (In Puleng, N.S. Le diphiri di tla Utologa. Pretoria: Kagiso Publishers. p. 21-42.)

RIMMON-KENAN, S. 1983. Narrative fiction: contemporary poetics. London: Methuen.

STRACHAN, A. 1990. Time in Ntuli's short stories with specific reference to "Uthingo Lwenkosazana". South African Journal of African Languages, 10(3):98-108.

SWANEPOEL, C.B. 1989. Prolepsis en analepsis: aspekte van temporale volgorde in die verhaalkuns toegepas op 'n kortverhaal deur E.M. Ramaila. Suid-Afrikaanse Tydskrif vir Afrikatale, 9(2):79-86.

\section{Key concepts:}

flashback: technique of; kinds of narrative technique

mystery

\section{Kernbegrippe:}

terugflits: tegniek van; soorte

narratiewe tegniek

geheim 
